\title{
The Role of the Ethnographic Vocabulary in the English and Uzbek Languages
}

\author{
Kayumova Nigora Muxtorovna, Shukurova Nigora Shavkatovna, Safoeva Sadokat Nasilloevna
}

\begin{abstract}
Various aspects of language and culture are currently the focus of attention of linguists, ethnolinguists, sociolinguists, psycholinguists, and cultural studies. It is the reflection in the language of ethnic and personal self-knowledge, ways of perceiving and conceptualizing the world, the formation of symbols and stereotypes inherent in certain people. Culture of a people is reflected in the values of linguistic units i.e. that stably fixed in them is invariant in content, knowledge of the language, and in terms of their ability to convey information over time, ranging in size and connotations, knowledge of which may not be necessary for the knowledge of the language. Cultural studies of vocabulary and in whole the language is the main point of our paper.
\end{abstract}

Keywords: Ethnolinguistics, cultural studies, language units, vocabulary, lacune, variants, ethnology, culture, linguistics, descriptive, statistical method.

\section{INTRODUCTION}

\section{Ethnolinguistics (sometimes}

called cultural

linguistics) is a field of linguistics that studies the relationship between language and culture and how different ethnic groups perceive the world. $[5,20]$ It is the combination between ethnology and linguistics. The former refers to the way of life of an entire community: all the characteristics that distinguish one community from the other. Such characteristics make the cultural aspects of a community or a society.

The word 'ethnography' is derived from the Greek है $\theta v o \varsigma$ (ethnos), meaning "a company, later a people, nation" and -graphy, meaning "writing". Ethnographic studies focus on large cultural groups of people who interact over time. Ethnography is a set of qualitative methods that are used in social sciences that focus on the observation of social practices and interactions. Its aim is to observe a situation without imposing any deductive structure or framework upon it and to view everything as strange or unique. It is becoming increasingly clear that the area of expertise is in linguistics, while the scope of meaning requires knowledge of cultural realities, content semi sphere certain historical period. Without this, it is impossible to adequately understand the

Revised Manuscript Received on July 22, 2019

Kayumova Nigora Muxtorovna, A teacher of Bukhara State University, Uzbekistan. Email: nigora_kayumova_2016@mail.ru

Shukurova Nigora Shavkatovna, A teacher of Bukhara State University, Uzbekistan. Email: nigorash@yahoo.com

Safoeva Sadokat Nasilloevna, A teacher of Bukhara State University, Uzbekistan. Email sadosh@list.ru meaning of the texts read. If we assume for the beginning of this division at least, we can distinguish those parts of culture in its historical process, which have a significant impact on society and the knowledge required for the perception of meanings transmitted speech works.

\section{MATERIALS AND METHODS}

In this article we used descriptive (analysis and syntheses on the basis of linguistic study of the literature on the theme of the investigation); distributive (the method of study of meanings in surroundings); statistical (qualitative study of the results of the investigation); method of dictionary textual comment.

In linguistic and methodological literature are widely used terms "cultural studies", "cultural studies", "linguistics." In some disciplines it is divided into ethnolinguistics, sociolinguistics, and psycholinguistics. [4, 17-40]

The problem of "language and culture" has become the object of study of many scientists (E. M. Vereshchagin, V.G.Kostomarov, G. D. Tomahin, S. G. Ter-Minasova, V.V. Vorobev and A.L.Berdichevsky and etc.) and develops as a purely self-direction - "linguocuturology". We consider the reflection of linguistics in the language of spirituality, catholicity, the categories associated with the philosophy of national character and mentality (Yu.N.Karaulov, G.D. Tomahin, Yu.S.Sorokin, L.P. Krysin and etc.). In each language, you can go from the spirit and language of the various phenomena associated with language mentality There are national and cultural peculiarities of speech communication organizations' behavior, the organization of the content of the speech utterance. In using the term "linguistics", we mean intercultural communication, language, intercultural communication, cultural anthropology. "Whorf argued that we all live in a kind of intellectual prison, whose walls were built by structural rules of our language. This is very strange prison, because we usually are not aware of the fact of his detention. We begin to realize this only when the collision of cultures ". It is the assimilation of a foreign (non-native) language specific to certain carriers" of the language means "understanding and categorization of the subject and the social reality".

According to the representatives of cultural linguistics (V. N. Teliya, V. V. Vorobyov, V. A. Maslova) this branch of linguistics has recently appeared "to the study and description of the correspondence of language and culture in their synchronic interaction".

V. A. Maslova points out the following objects of cultural 
linguistics: first of all there are words and phrases, which have no equivalents in another language; then: archetypes, rituals, beliefs, and superstitions reflected in a language; on the third place there are proverbs and sayings; 4) idioms; 5) symbols and stereotypes; 6) metaphors and images; end the last stylistic of norms and speech behavior. The study links between the linguistic and cultural phenomena involved ethnolinguistics. In the broadest sense of the word ethnolinguistics - the science that studies the relationship between ethnicity and language in all its diversity. It intersects with such branches of the humanities as sociolinguistics and psycholinguistics, ethnology and ethnography of communication, folklore, mythology, and poetics. Subject ethnolinguistics covers areas such as language and traditional culture, language and ethnic specificity of thinking, ethno-linguistic processes in domestic and inter-ethnic contacts.

It should be noted that in the Uzbek there are few works on ethnolinguistic study. While ethnolinguistics is booming on the basis of the Slavic and other languages. In Slavic linguistics, one of the first founders of this field is Academician N. Tolstoy. In his paper "On the subject of ethnolinguistics and its role in the study of language and ethnicity," he defines ethnolinguistics as "a branch of linguistics or wider - the direction in linguistics, orienting the researcher to consider the relation of language and communication, and spiritual culture, language and people's mentality, language and folk creativity, their interdependence and different types of correspondence. Ethnoliguistics is not a simple hybrid of linguistics and ethnology, or a mixture of individual elements of both. It is a science, as well as several other mixed disciplines, clearly defining aspect in which language forms and functions"(Tolstoy 1983:182).

In our case, this aspect is the ethnographic vocabulary. According to the academician, the language in ethnolinguistics "always remains the main focus of the study, regardless of what kind of substance (linguistic or nonlinguistic) and which function (ritual, communication, mythological, etc.) are subject to review" (Tolstoy 1983:182) study of language in cultural-historical context, it is "an additional source, and in some cases, the decisive criterion for Reconstruction original meaning of the word, and the direction of its semantic evolution" (Tolstoy 1983:182). Since ethnolinguistics - scientific field, border between linguistics and ethnology, the ethno-linguistic studies are impossible without the data of ethnography and linguistics. If ethnographers consider the reflection of the ethnic characteristics of the material and spiritual culture, traditions and customs in the subject that linguists need to know what the results of scientific research have folklorists and ethnographers.

\section{DISCUSSION}

There are different ways of translation of ethnographisms in English and Uzbek languages. In this paragraph we are going to analyze ethnographisms by the ways of translation techniques.

Direct translation techniques include:
Borrowing is the taking of words directly from one language into another without translation. Many English words are "borrowed" into other languages; for example software in the field of technology and funk in culture.

For example: Nowruz - the spring festival of charity. From the Ancient times Navruz is the most cheerful holiday in Central Asia. For more than 3 centuries people of Central and East Asia celebrate Navruz as the holiday. The word is derived from Tadjik nav-meaning "new", ro'z-meaning "day". This word is borrowed to Uzbek from one of the Indo European family of languages (Tadjik)

Calque. A calque or loan translation (itself a calque of German Lehnübersetzung) is a phrase borrowed from another language and translated literally word-for-word. You often see them in specialized or internationalized fields such as quality assurance. Some calques can become widely accepted in the target language.

For example,

Kelin salom - greetings of bride. The bride makes greeting with a bow from the porch to everyone who is present at this time in the house.

Nahorgi osh - morning pilaf. The national dish - rice, designed for 200-300 people, which are served at 5:00 am. Are invited exclusively by men.

Sochqi sochish - throwing sweets. Above the man who is born before you enter it in the house or after he entered the house, throw over his head and newborn candy, sugar cubes, candy to the child's life was sweet.

Literal Translation. A word-for-word translation can be used in some languages and not others dependent on the sentence structure. Ethnographims can also be translated by the way of literal translation. For example:

Qovurdoq kelishi - parents of bride, having heard the glad tidings, prepared to leave his daughter and the baby from the hospital, "kovurdok," (the national dish - slices of roast meat and eggs (so life went on, and daughter recovering). Kovurdok bride was escorted relatives (mother, her sister , aunts, grandmothers), and each prepares togora (large cup with the Uzbek national dishes: Samosas, Barak-national cakes, Noreen, manti - Baking dish with meat, horse meat and beef, etc).

Supra qoqdi - feast of late guests who missed the main meal, the last child in a large family.

Oblique translation techniques include:

Transposition- This is the process where parts of speech change their sequence when they are translated (blue ball becomes boule bleue in French). It is in a sense a shift of word class. Grammatical structures are often different in different languages.

Modulation- consists of using a phrase that is different in the source and target languages to convey the same idea: It changes the semantics and shifts the point of view of the source language. Through modulation, the translator generates a change in the point of view of the message without altering meaning and without generating a sense of awkwardness in the reader of the target text. It is often used within the same language.

Reformulation

Published By:

Blue Eyes Intelligence Engineering 
Equivalence- Here you have to express something in a completely different way, for example when translating idioms or advertising slogans. The process is creative, but not always easy.

Adaptation- Adaptation occurs when something specific to one language culture is expressed in a totally different way that is familiar or appropriate to another language culture. It is a shift in cultural environment. For example:

Hol-ahvol so'rash - greeting. Women hug when they met, and men bow, putting his right hand to his heart, followed by a handshake.

Compensation- In general terms compensation can be used when something cannot be translated, and the meaning that is lost is expressed somewhere else in the translated text. As Louise M. Haywood from the University of Cambridge puts it, "we have to remember that translation is not just a movement between two languages but also between two cultures. Cultural transposition is present in all translation as degrees of free textual adaptation departing from maximally literal translation, and involves replacing items whose roots are in the source language culture with elements that are indigenous to the target language. The translator exercises a degree of choice in his or her use of indigenous features, and, as a consequence, successful translation may depend on the translator's command of cultural assumptions in each language in which he or she works".

For example:

Chilla saqlamoq - comply with chilla. New mother with a baby 40 days should not go out and talk to someone (in order not to get sick, and touch wood baby)

Qovurdoq sarupolari - the mother gives son in-law, daughter clothing, shoes, newborn diaper, and sliders, clothing

Vocabulary without equivalent background and all its subgroups: hontahta, zardevol, tun, kurpacha boshkalar .

Through television and radio receives a certain number of ethnographisms of the English in Uzbek language. From the interpreter is required true skill in interpreting unequivalented words in the text of art, and television by highlighting allows you to create a visual image (a new concept) of the national specific realities.

A screen adaptation, a huge number of works of writers of the XIX century, folk tales, puppet theater productions and cartoons on the subjects of English folk tales - in terms of techniques to overcome barriers ethnocultural.

The following examples are taken from newspapers and magazines. They suggest that the press gets into the language a lot of ethnographisms of English and foreign origin. In the Uzbek language from Russian were included words such as : cartridge, laptop, joystik, CD-ROM, CD, DVD, file, floppy Drive, sponsor, hamburger, rating, blackout, monitoring, leasing, auditor, the sponsor, racketeering, hacker, disk jockey, supermarket, video, Multimedia, Bachelor Degree, Master, etc.

Due to the rapid development of contacts between representatives of different cultures and the active entry of Uzbekistan into the world community via television and radio, via the Internet comes a huge amount of new vocabulary. For example, realities of e-mail consulting, briefing, presentation, sponsor, image, image maker, design, designer, mentality, printer, modem, tuner, etc.

Balogardon- a person who helps others to avoid misfortune. The second name of Bakhouddin Nakshband which means to get rid of sorrows.

Baraka-blessing power. Abundance of harvest much more than expected.

These Uzbek ethnographisms are growing in popularity and has entered the vocabulary of many languages.

Uzbek ethnographisms hashar, mahalla, dehqon, kelin, qozon, eshik, to'y, iftor, oqsoqol, rais, choykhona,xovuz, qishloq gradually emerge on the world stage, as evidenced by the following examples:

"Rural households in Uzbekistan have been described as patriarchal and extended with brides (kelin: from the Uzbek verb kelmoq: to come) moving to the household of their husband's family" Johan Rasanayagan. Spheres of communal participation: placing the state within local modes of interaction in rural Uzbekistan.[3, 60] "These extended household usually eat their meals together" (bir qozon: one cooking pot), (the same magazine, p.60).

"One son, typically the youngest, will continue living in the family", (the same magazine, p.60).

"Hashar might seem to belong to a different category than the road-building project", (the same magazine, p.64).

"The villages making up such a unit were known as qozonsherik (sharing one cooking pot) reflecting the fact that they constituted a social unit as well", (p.67).

"The host invited the mahalla oqsoqol, the mulla and other olden men from the two neighboring streets and the reason he gave for organizing the meal was to show respect to those attending, to repay the times his father had attended similar gatherings in his old age and because he had not held a wedding celebration for the past five years since his youngest sister's marriage "(p.67).

"Guzar is another, more specifically Central Asian term, which designates small bazaars but also wards in town s. Qavm is a third term, which is used for neighbourhood communities"

"In Khorezm the second meaning of qavm was emphasized when a group of farmsteads was called machit-qavm (mosque ward)", (the same magazine, p.97).

"Urgut, a village near Samarkand is said to have included 13 mahallahs". (P.98).

"This was not only due to the necessity of common maintenance and cleaning of water reservoirs (hovuz) and other common facilities", (p.99).

"In towns with strong Persian influence like Bukhara it was the only public place, since the tea house (choikhona) did not exist there". (P.99).

There existed often a rais who observed the resident's attendance at the first prayer, (p.99).

An Uzbek tribe could acknowledge the khan or the emir as supreme owner of all land (p. 102).

Eastern 
villages rather consisted of several generations.

\section{CONCLUSION}

As can be seen from the examples ethnographisms of one language into other languages can be translated according:

a) By the historical, spiritual, cultural, socio- political contacts;

b) By disseminating scientific and technological discoveries;

c) By the translation of literary art works;

d) By the use of non-native writers, translators lacunae of the national language.

The main methods for the transfer of Russian (or borrowed through the Russian language) gaps in the Uzbek language are transliterated and creating a new word (phrase) for the corresponding effects on the existing items in the language.

\section{REFERENCES}

1. Abazov R. Culture and Customs of the Central Asian Republics. London. Greenwood Press, 2007 - 325 p

2. Raul George Geiss. Mahallah and kinship relation. Central Asian Survey (2001), 20 (1), p.97.

3. Central Asian Survey magazine (2002).21 (1) p.60.

4. Underhill, J.Ethnolinguistics and Cultural Concepts: Truth, Love, Hate and War (pp. 17-40). Cambridge: Cambridge University Press. 2012 doi:10.1017/CBO9780511862540.003

5. Ferraro, Gary. Cultural Anthropology: An Applied Perspective. Cengage Learning. 2006

6. Лучинина Е.Н. Лингвокультурология в системе гуманитарного знания. ТГУ. Критика и семиотика. Вып. 7 2004.http://www.nsu.ru/education/virtual/cs7luchinina.htm

7. Маслова В.А. Лингвокультурология. - М.: Академия, 2001. http://www.englspace.com/dl/files/maslova.zip

8. Oxford Learner - Oxford Advanced Learner's Dictionary of Current English:In 2v. V1. Oxford UP, 1980 